\title{
Perspektif Holland Theory serta Aplikasinya dalam Bimbingan dan Konseling Karir
}

\author{
Berru Amalianita1, Yola Eka Putri1 \\ 1Indonesian Institute for Counseling, Education and Theraphy (IICET) \\ *Corresponding author, e-mail: berruamalianita10@gmail.com
}

\begin{abstract}
:
Teori Holland memandang kepribadian memiliki karakteristik yang unik, yang berkembang dari faktor genetik dan pengaruh lingkungan.Teori Holland memberikan perhatian pada tipe kepribadian sebagai penyebab utama dalam pilihan tipe lingkungan pekerjaan.Holland membagi enam tipe kepribadian dan enam tipe lingkungan pekerjaan. Adapun keenam tipe tersebut adalah realistik, investigatif, artistik, sosial enterprising, dan konvensional. Teori Holland sangatlah penting untuk membangun suatu keterkaitan atau kecocokan antara tipe kepribadian individu dan pemilihan karir tertentu. Pemilihan dan penyesuaian karir merupakan gambaran dari kepribadian seseorang. Melalui enam tipe kerpribadian mengemukakan bahwa kepuasan dan kecenderungan untuk meninggalkan satu posisi bergantung pada tingkat samapai mana individu secara berhasil mencocokkan kepribadiannya dengan suatu pekerjaan serta memiliki pekerjaan yang sepadan.
\end{abstract}

Keywords: Holland Theory, BK Karir

This is an open access article distributed under the Creative Commons Attribution License, which permits unrestricted use, distribution, and reproduction in any medium, provided the original work is properly cited. @ 2019 by author

\section{PENDAHULUAN}

Untuk membantu anak dalam mengembangkan diri secara optimal sehingga dapat merencanakan pencapaian pekerjaan sebagai landasan karier yang seslla dengan kemampuan, bimbingan karier sebagai salah satu bidang layanan bimbingan konseling sangat dibutuhkan (Rosita, Irmayanti, \& Hendriana, 2020; Suprihatin, 2015). Karena bimbingan karier merupakan bimbinganyang mencakup kegiatan bimbingan kepada siswa dari memilih, menyiapkan diri, mencari dan menyesuaikan diri terhadap karier (Juwitaningrum, 2013). Dengan layanan bimbingan karier yang sudah diberikan diharapkan siswa dapat memahami karakteristik dirinya dalam hal minat, nilai-nilai, kecakapan dan ciri-ciri kepribadian serta dapat rnengidentifikasikan bidang pekerjaan yang luas, yang mungkin lebih cocok bagi rnereka selanjutnya diharapkan siswa dapat menemukan karier dan melaksanakan karier yang efektif serta memberikan kelayakan hidup (Nindya, Kiswantoro, \& Hidayati, 2020; Suryani, 2020). 
Bimbingan karier merupakan salah satu aspek bimbingan perkembangan, sehingga sangat diperlukan sepanjang perkembangan anak, lebih baik jika bimbingan itu diberikan ke anak sejak rnasa kanak-kanak bahkan sebelun masuk sekolah, yang diteruskan di masa sekolah dasar, di sekolah lanjutan dan di perguruan tinggi, bahkan mungkin masih diperlukan sewaktu seseorang sudah memasuki dunia kerja, dengan harapan bahwa dengan bimbingan yang diberikan akan membantu dalam penyesuaian diri dengan sifat dan situasi kerja (Haolah, Rohaeti, \& Rosita, 2020; Rahmawati, Yusmansyah, \& Mayasari, 2020). Dengan demikian melalui teori ini dapat menambah wawasan konselor dalam membantu klien memutuskan pilihan karier.

Aplikasi Teori Holland di Sekolah sangat relevan bagi bimbingan karier dan konseling karier di institusi pendidikan untuk jenjang pendidikan menengah dan masa awal pendidikan tinggi (Winkel \& Hastuti, 2005). Tekanan yang diberikan pada pemahaman diri sehubungan dengan beberapa kualitas vokasional yang dimiliki seseorang dan pada informasi yang akurat mengenai berbagai lingkungan okupasi, menyadarkan lembaga bimحbingan akan tugasnya untuk membantu orang muda mengenal diri sendiri dan mengenal ciri-ciri lingkungan, $\mathrm{k}$ edua hal ini sangat diperlukan sebagai masukan dalam memikirkan pilihan okupasi secara matang.

dalam memikirkan pilihan okupasi secara matang (Tama, 2019; Winkel \& Hastuti, 2005).Holland berpegang pada keyakinan, bahwa suatu minat yang menyangkut pekerjaan dan okupasi adalah hasil perpaduan dari sejarah hidup seseorang dan keseluruhan kepribadiannya, sehingga minat tertentu akhirnya menjadi suatu ciri kepribadian yang berupa ekspresi diri dalam bidang pekerjaan, bidang studi akademik, hobi inti, berbagai kegiatan rekreatif dan banyak kesukaan yang lain (Bonitz, Armstrong, \& Larson, 2010)

\section{Konsep Dasar Teori Holland}

Pertama kali diusulkan pada tahun 1959, teori Holland dikonseptualisasikan sebagai teori sifat dan faktor dan "tetap dalam tradisi psikologi diferensial". Awalnya diusulkan sebagai teori pilihan kejuruan, teori Holland's baru-baru ini berjudul "teori kepribadian kejuruan dan lingkungan kerja" untuk mencerminkan penyempurnaan teoritis. Secara signifikan, karya Holland telah mempengaruhi perkembangan persediaan minat, penilaian karir, klasifikasi informasi pekerjaan, dan konseling karir (Patton \& McMahon, 2014).

Teori pilihan karir yang dikembangkan oleh John L. Holland adalah salah satu teori pengembangan karier yang paling banyak diteliti dan diterapkan. Berdasarkan pada premis bahwa faktor-faktor kepribadian mendasari pilihan karir, teorinya mendalilkan bahwa orang memproyeksikan pandangan dunia dan pekerjaan ke jabatanjabatan dan membuat keputusan karier yang memuaskan orientasi pribadi pilihan mereka. Teori ini menggabungkan beberapa konstruksi dari psikologi kepribadian, perilaku kejuruan, dan psikologi sosial, termasuk teori persepsi diri dan stereotip sosial (Foutch, McHugh, Bertoch, \& Reardon, 2014).

Penerapan teori pilihan karir Holland melibatkan penilaian individu dalam hal dua atau tiga tipe kepribadian yang menonjol dan kemudian mencocokkan tipe masing-masing dengan aspek lingkungan dari karir potensial. Teori ini memprediksi bahwa semakin tinggi derajat kesesuaian antara karakteristik individu dan pekerjaan, semakin baik potensi untuk hasil positif terkait karir, termasuk kepuasan, kegigihan, dan prestasi (Lent, Sheu, \& Brown, 2010).

Dalam beberapa dekade terakhir, teori Holland telah memandu penilaian kepentingan karir baik di Amerika Serikat maupun internasional. Teori Holland menawarkan kerangka tipologi sederhana dan mudah dipahami mengenai minat dan lingkungan karir yang dapat digunakan dalam konseling dan bimbingan karir (Yusuf \& Hasnidar, 2020). Holland mendalilkan bahwa minat vokasional adalah ekspresi kepribadian seseorang, dan bahwa kepentingan kejuruan dapat dikonseptualisasikan ke dalam enam tipologi, yaitu Realistis (R), Investigasi (I), Artistik (A), Sosial (S), Enterprising (E), dan Konvensional (C). Jika tingkat kemiripan seseorang dengan enam kepribadian dan jenis minat dapat dinilai, mungkin untuk menghasilkan kode tiga huruf (misalnya, SIA, RIA) untuk menunjukkan dan merangkum minat karir seseorang. Huruf pertama dari kode tersebut adalah jenis minat utama seseorang, yang kemungkinan akan memainkan peran utama dalam pilihan dan kepuasan karir. Huruf kedua dan ketiga adalah tema minat sekunder, dan kemungkinan besar akan memainkan peran yang lebih rendah namun tetap penting dalam proses pilihan karir (Leung, 2008).

Teori pilihan karir John Holland (RIASEC) menyatakan bahwa dalam memilih karir, orang lebih suka pekerjaan di mana mereka bisa berada di sekitar orang lain yang seperti mereka. Mereka mencari lingkungan yang akan memungkinkan mereka menggunakan keterampilan dan kemampuan mereka, dan mengekspresikan 
sikap dan nilai-nilai mereka, sambil mengambil masalah dan peran yang menyenangkan. Perilaku ditentukan oleh interaksi antara kepribadian dan lingkungan (Hurtado Rúa, Stead, \& Poklar, 2019; McKay \& Tokar, 2012).

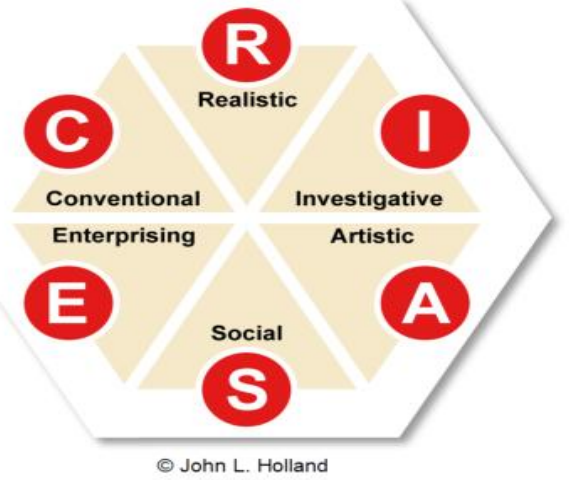

Gambar 1: Holland's Hexagon

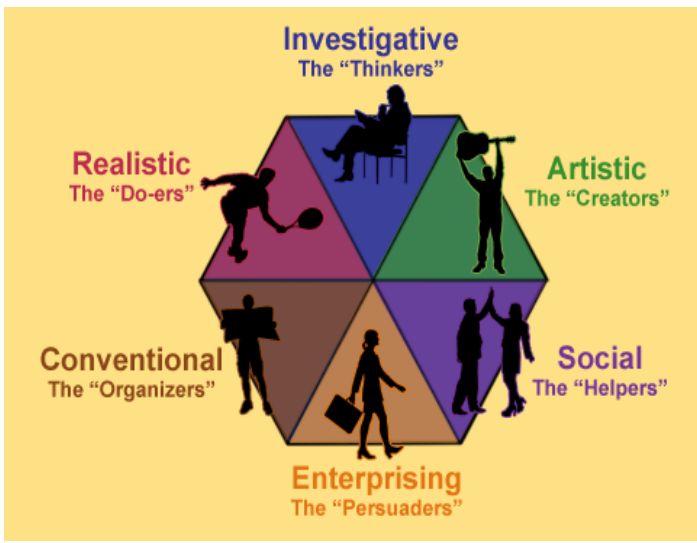

Sumber: https://www.careers.govt.nz

\section{KARAKTERISTIK TEORI HOLLAND}

Holland menegaskan bahwa ada keterkaitan antara karakter kepribadian, lingkungan dan pekerjaan yang memungkinkan mereka mengasah keterampilan dan kemampuan, mengungkapkan sikap dan nilai-nilai yang mereka yakini dan hal-hal sejenis lainnya (Rahmi, 2017). Karir ditentukan oleh interaksi antara kepribadian kita dan lingkungan dalam Theory of Career Choice karya John Holland. "We want jobs with people like us" (Putri \& Sari, 2018). Holland menegaskan bahwa orang-orang dari tipe kepribadian yang sama yang bekerja bersama dalam suatu pekerjaan menciptakan lingkungan yang cocok dan menghargai tipe mereka (Sheu, et al., 2010). Berikut penjelasan dari ke-enam tipe kepribadian yang disebutkan dalam teori karir John Holland (Wille \& De Fruyt, 2014).

\section{Realistic}

\begin{tabular}{llll}
\hline Deskripsi bidang minat & $\begin{array}{l}\text { Beberapa keterampilan } \\
\text { kunci }\end{array}$ & $\begin{array}{l}\text { Beberapa pekerjaan } \\
\text { dengan komponen } \\
\text { Realistis }\end{array}$ & $\begin{array}{l}\text { Mata pelajaran } \\
\text { yang bisa dipelajari } \\
\text { untuk memberi kan } \\
\text { keterampilan }\end{array}$ \\
\hline
\end{tabular}

\section{Suka bekerja terutama} dengan tangan, membuat, memperbaiki, merakit atau membangun sesuatu, menggunakan dan mengoperasikan peralatan, alat atau mesin. Seringkali suka bekerja di luar ruangan

Menggunakan dan
mengoperasikan alat, peralatan
dan mesin, merancang,
membangun, memperbaiki,
memelihara, bekerja secara
manual, mengukur, bekerja
secara detail, mengemudi,
bergerak, merawat hewan,
bekerja dengan tanaman

\begin{tabular}{|c|c|}
\hline $\begin{array}{l}\text { Pilot, petani, } \\
\text { hortikultura, } \\
\text { pembangun, insinyur, } \\
\text { personel angkatan } \\
\text { bersenjata, mekanik, } \\
\text { tukang melapis, } \\
\text { listrik, teknolog } \\
\text { komputer, penjaga } \\
\text { taman, olahragawan }\end{array}$ & $\begin{array}{l}\text { Bahasa Inggris, } \\
\text { Matematika, Sains, } \\
\text { Workshop, } \\
\text { Teknologi, } \\
\text { Komputer, Studi } \\
\text { Bisnis, Pertanian, } \\
\text { Hortikultura, } \\
\text { Pendidikan Jasmani }\end{array}$ \\
\hline
\end{tabular}

\section{Investigative}

\begin{tabular}{|c|c|c|c|}
\hline Deskripsi bidang minat & $\begin{array}{l}\text { Beberapa keterampilan } \\
\text { kunci }\end{array}$ & $\begin{array}{l}\text { Beberapa pekerjaan } \\
\text { dengan komponen } \\
\text { Investigatif }\end{array}$ & $\begin{array}{l}\text { Mata pelajaran } \\
\text { yang bisa dipelajari } \\
\text { untuk memberi kan } \\
\text { keterampilan }\end{array}$ \\
\hline $\begin{array}{l}\text { Suka menemukan dan } \\
\text { meneliti ide, mengamati, } \\
\text { menyelidiki, dan } \\
\text { bereksperimen, } \\
\text { mengajukan pertanyaan, } \\
\text { dan menyelesaikan } \\
\text { masalah }\end{array}$ & $\begin{array}{l}\text { Berpikir analitis dan logis, } \\
\text { menghitung, berkomunikasi } \\
\text { dengan menulis dan } \\
\text { berbicara, merancang, } \\
\text { merumuskan, menghitung, } \\
\text { mendiagnosis, } \\
\text { bereksperimen, menyelidiki }\end{array}$ & $\begin{array}{l}\text { Ilmu pengetahuan, } \\
\text { penelitian, pekerjaan } \\
\text { medis dan kesehatan, ahli } \\
\text { kimia, ilmuwan kelautan, } \\
\text { teknisi kehutanan, teknisi } \\
\text { laboratorium medis atau } \\
\text { pertanian, ahli zoologi, }\end{array}$ & $\begin{array}{l}\text { Bahasa Inggris, } \\
\text { Matematika, Sains, } \\
\text { Komputer, Teknologi }\end{array}$ \\
\hline
\end{tabular}




\section{Artistic}

\begin{tabular}{|c|c|c|c|}
\hline Deskripsi bidang minat & $\begin{array}{l}\text { Beberapa keterampilan } \\
\text { kunci }\end{array}$ & $\begin{array}{l}\text { Beberapa pekerjaan } \\
\text { dengan komponen } \\
\text { Artistik }\end{array}$ & $\begin{array}{l}\text { Mata pelajaran yang } \\
\text { bisa dipelajari untuk } \\
\text { memberi kan } \\
\text { keterampilan }\end{array}$ \\
\hline $\begin{array}{l}\text { Suka menggunakan kata- } \\
\text { kata, seni, musik atau drama } \\
\text { untuk berkomunikasi, } \\
\text { melakukan, atau } \\
\text { mengekspresikan diri, } \\
\text { membuat dan merancang } \\
\text { sesuatu }\end{array}$ & $\begin{array}{l}\text { Mengekspresikan secara } \\
\text { artistik atau fisik, } \\
\text { berbicara, menulis, } \\
\text { menyanyi, tampil, } \\
\text { merancang, menyajikan, } \\
\text { merencanakan, menyusun, } \\
\text { bermain, menari }\end{array}$ & $\begin{array}{l}\text { Artis, ilustrator, } \\
\text { fotografer, penulis lagu, } \\
\text { komposer, penyanyi, } \\
\text { pemain instrumen, } \\
\text { penari, aktor, reporter, } \\
\text { penulis, editor, } \\
\text { pengiklan, penata } \\
\text { rambut, perancang } \\
\text { busana }\end{array}$ & $\begin{array}{l}\text { Bahasa Inggris, Ilmu } \\
\text { Sosial, Musik, Drama, } \\
\text { Seni, Desain Grafis, } \\
\text { Komputer, Studi Bisnis, } \\
\text { Bahasa }\end{array}$ \\
\hline
\end{tabular}

\section{Social}

\begin{tabular}{|c|c|c|c|}
\hline Deskripsi bidang minat & $\begin{array}{l}\text { Beberapa keterampilan } \\
\text { kunci }\end{array}$ & $\begin{array}{l}\text { Beberapa pekerjaan } \\
\text { dengan komponen } \\
\text { Sosial }\end{array}$ & $\begin{array}{l}\text { Mata pelajaran yang } \\
\text { bisa dipelajari untuk } \\
\text { memberi kan } \\
\text { keterampilan }\end{array}$ \\
\hline $\begin{array}{l}\text { Suka mengajar, melatih dan } \\
\text { memberi informasi, } \\
\text { membantu, mengobati, } \\
\text { menyembuhkan dan melayani } \\
\text { dan menyapa, peduli dengan } \\
\text { kesejahteraan diri dan } \\
\text { kesejahteraan orang lain }\end{array}$ & $\begin{array}{l}\text { Berkomunikasi secara lisan } \\
\text { atau tertulis, peduli dan } \\
\text { mendukung, melatih, } \\
\text { bertemu, menyapa, } \\
\text { membantu, mengajar, } \\
\text { memberi informasi, } \\
\text { mewawancarai, melatih }\end{array}$ & $\begin{array}{l}\text { Guru, perawat, asisten } \\
\text { perawat, penasihat, } \\
\text { petugas polisi, pekerja } \\
\text { sosial, tenaga } \\
\text { penjualan, petugas } \\
\text { layanan pelanggan, } \\
\text { pelayan, sekretaris }\end{array}$ & $\begin{array}{l}\text { Bahasa Inggris, Ilmu } \\
\text { Sosial, Matematika, } \\
\text { Sains, Kesehatan, } \\
\text { Pendidikan Jasmani, } \\
\text { Seni, Komputer, Studi } \\
\text { Bisnis, Bahasa }\end{array}$ \\
\hline
\end{tabular}

\section{Enterprising}

\begin{tabular}{|c|c|c|c|}
\hline $\begin{array}{l}\text { Deskripsi bidang } \\
\text { minat }\end{array}$ & $\begin{array}{l}\text { Beberapa keterampilan } \\
\text { kunci }\end{array}$ & $\begin{array}{l}\text { Beberapa pekerjaan } \\
\text { dengan komponen } \\
\text { Enterprising }\end{array}$ & $\begin{array}{l}\text { Mata pelajaran yang } \\
\text { bisa dipelajari untuk } \\
\text { memberi kan } \\
\text { keterampilan }\end{array}$ \\
\hline $\begin{array}{l}\text { Suka bertemu orang, } \\
\text { memimpin, berbicara } \\
\text { dan mempengaruhi } \\
\text { orang lain, mendorong } \\
\text { orang lain, bekerja } \\
\text { dalam bisnis }\end{array}$ & $\begin{array}{l}\text { Menjual, mempromosikan dan } \\
\text { membujuk, mengembangkan } \\
\text { ide-ide, berbicara di depan } \\
\text { umum, mengelola, mengatur, } \\
\text { memimpin dan menangkap, } \\
\text { menghitung, merencanakan }\end{array}$ & $\begin{array}{l}\text { Tenaga penjual, } \\
\text { pengacara, politisi, } \\
\text { akuntan, pemilik bisnis, } \\
\text { eksekutif atau manajer, } \\
\text { agen perjalanan, musik } \\
\text { atau promotor olahraga }\end{array}$ & $\begin{array}{l}\text { Bahasa Inggris, } \\
\text { Matematika, Studi } \\
\text { Bisnis, Akuntansi, } \\
\text { Ekonomi, Ilmu Sosial, } \\
\text { Drama, Komputasi, } \\
\text { Manajemen Informasi } \\
\text { Teks, Bahasa }\end{array}$ \\
\hline
\end{tabular}

\section{Conventional}

\begin{tabular}{|c|c|c|c|}
\hline Deskripsi bidang minat & $\begin{array}{l}\text { Beberapa keterampilan } \\
\text { kunci }\end{array}$ & $\begin{array}{l}\text { Beberapa pekerjaan } \\
\text { dengan komponen } \\
\text { Konvensional }\end{array}$ & $\begin{array}{l}\text { Mata pelajaran } \\
\text { yang bisa dipelajari } \\
\text { untuk memberi kan } \\
\text { keterampilan }\end{array}$ \\
\hline $\begin{array}{l}\text { Suka bekerja di dalam } \\
\text { ruangan dan pada tugas-tugas } \\
\text { yang melibatkan } \\
\text { pengorganisasian dan akurasi, } \\
\text { mengikuti prosedur, bekerja } \\
\text { dengan data atau angka, } \\
\text { pekerjaan perencanaan dan } \\
\text { acara }\end{array}$ & $\begin{array}{l}\text { Komputasi dan keyboarding, } \\
\text { merekam dan menyimpan } \\
\text { catatan, memperhatikan } \\
\text { detail, bertemu dan menyapa, } \\
\text { melakukan perhitungan, } \\
\text { menangani uang, mengatur, } \\
\text { mengatur, bekerja secara } \\
\text { mandiri }\end{array}$ & $\begin{array}{l}\text { Sekretaris, } \\
\text { resepsionis, pekerja } \\
\text { kantor, pustakawan, } \\
\text { petugas bank, } \\
\text { operator komputer, } \\
\text { toko dan petugas } \\
\text { pengiriman }\end{array}$ & $\begin{array}{l}\text { Bahasa Inggris, } \\
\text { Matematika, Studi } \\
\text { Bisnis, Akuntansi, } \\
\text { Ekonomi, Komputer, } \\
\text { Manajemen } \\
\text { Informasi Teks }\end{array}$ \\
\hline
\end{tabular}


Teori Holland mengambil pendekatan pemecahan masalah dan kognitif untuk perencanaan karir. Modelnya sangat berpengaruh dalam konseling karier. Ini telah digunakan melalui alat penilaian populer seperti Penelusuran Arahan Langsung, Inventarisasi Preferensi Kejuruan dan Inventarisasi Minat Kuat (Bonitz, et al., 2010; Ludwikowski, 2013).

Menurut Holland (Sheldon, Holliday, Titova, \& Benson, 2020; Smart, Feldman, \& Ethington, 2000) beberapa karakteristik teori pilihan karir John Holland adalah:

1. Setiap orang adalah satu dari enam tipe kepribadian: Realistis, Investigatif, Artistik, Sosial, Enterprising, dan Konvensional. Beberapa menyebut ini sebagai Kode Holland atau RIASEC.

2. Orang-orang dari tipe kepribadian yang sama yang bekerja bersama menciptakan lingkungan kerja yang sesuai dengan tipenya. Misalnya, ketika orang Artistik bersama dalam suatu pekerjaan, mereka menciptakan lingkungan kerja yang menghargai pemikiran dan perilaku kreatif - lingkungan Artistik.

3. Orang mencari lingkungan di mana mereka dapat menggunakan keterampilan dan kemampuan mereka dan mengekspresikan nilai dan sikap mereka. Misalnya, tipe Investigative mencari lingkungan Investigative; Jenis artistik mencari lingkungan Artistik, dan sebagainya.

4. Orang yang memilih untuk bekerja di lingkungan yang mirip dengan tipe kepribadiannya lebih mungkin berhasil dan puas. Misalnya, orang Artistik lebih mungkin berhasil dan puas jika mereka memilih pekerjaan yang memiliki lingkungan Artistik, seperti memilih untuk menjadi guru tari di sekolah menari - lingkungan "didominasi" oleh orang-orang tipe Artistik di mana kemampuan kreatif dan ekspresi sangat dihargai.

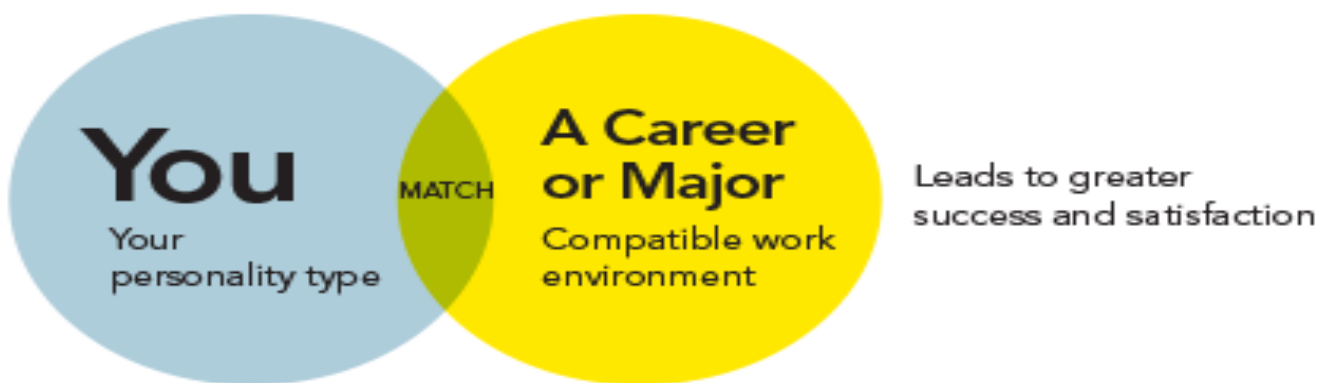

Gambar 1: Match personality Sumber: https://www.careers.govt.nz

\section{KEKUATAN DAN KELEMAHAN TEORI HOLLAND}

Kekuatan teori Holland dinilai sebagai teori komperhensif karena meninjau pilihan okupasi sebagai bagian dari keseluruhan pola hidup individu dan sebagai teori yang mendapatkan banyak dukungan dari hasil penelitian sejauh menyangkut modal-modal lingkungan serta kepribadian (Winkel \& Hastuti, 2005). Kekuatannya lainnya Teori pilihan karir yang dikembangkan oleh John Holland adalah salah satu teori pengembangan karir yang paling banyak diteliti dan diterapkan. Berdasarkan alasan bahwa faktor kepribadian yang mendasari pilihan karir, teorinya mendalilkan bahwa orang memproyeksikan pandangan kerja sendiri dan dunia kerja ke judul jabatan dan membuat keputusan karir yang sesuai dengan orientasi pribadi pilihan mereka. Teori ini menggabungkan beberapa konstruksi dari psikologi kepribadian, perilaku vokasional, dan psikologi sosial, termasuk teori persepsi diri dan stereotip sosial (Greenhaus \& Callanan, 2006).

Sedangkan kekurangan pada teori Holland adalah kurang ditinjau proses perkembangan yang melandasi keenam tipe kepribadian dan tidak menunjukkan fase-fase tertentu dalam proses perkembangan itu serta akumulasi rentang umur. Mengenai tahap-tahap atau tingkat yang dapat dicapai oleh seseorang dalam bidang okupasi tertentu, Holland menunjuk pada taraf intelegensi yang memungkinkan tingkat pendidikan sekolah tertent, namun dipertanyakan apakah masih ada faktor-faktor lainnya (Winkel \& Hastuti, 2005). Selanjutnya Teori fit person-environment pada umumnya menemukan beberapa dukungan, namun bukti validitas teori Holland agak lemah. Ini mungkin karena model Holland menyederhanakan gagasan kecocokan; tidak cukup memperhitungkan kecocokan antara kemampuan dan tuntutan pekerjaan; dan tidak memberi perhatian yang cukup terhadap pengaruh khas antara individu dan lingkungan kerja (bagaimana cara kerja mempengaruhi individu dan bagaimana individu mempengaruhi pekerjaan) (Michalos, 2010).

\section{RISET-RISET BERKENAAN DENGAN TEORI HOLLAND}

Beberapa hasi riset berkenaan dengan teori Holland adalah: 
1. Career interests of students in psychology specialties degrees: psychometric evidence and correlations with the RIASEC dimensions

Dalam studi ini, peneliti menyajikan pengembangan skala minat kejuruan untuk mahasiswa yang belajar psikologi. Tiga dimensi diekstraksi melalui analisis komponen utama, yaitu psikologi organisasi, pendidikan, dan klinis. Studi kedua dengan analisis faktor konfirmatori mereplikasi tiga faktor yang sama yang diperoleh dalam penelitian pertama. Kami menemukan korelasi positif yang signifikan antara psikologi klinis dan pendidikan dengan dimensi sosial model Holland. Dimensi giat tampaknya secara signifikan dan positif berkorelasi dengan komponen psikologi organisasi. Implikasi dan saran untuk penelitian masa depan dibahas (Ferreira, Rodrigues, \& da Costa Ferreira, 2016).

2. Interactive Effects of Physical Disability Severity and Age of Disability Onset on RIASEC Self-Efficacies

Dalam penelitian ini, penulis fokus pada konteks kecacatan fisik (yaitu, usia seseorang ketika kecacatan bermanifestasi dan tingkat keparahan yang berdampak pada kegiatan kehidupan utama) untuk lebih memahami bagaimana kecacatan memengaruhi efikasi diri kejuruan. Konsisten dengan Teori Karir Kognitif Sosial, usia onset memoderasi hubungan antara keparahan kecacatan dan self-efficacy dalam domain kejuruan Realistis, Artistik, Sosial, dan Konvensional. Secara khusus, keparahan kecacatan memiliki dampak negatif yang kuat pada kemanjuran diri bagi orang-orang yang menjadi cacat fisik di kemudian hari. Sebaliknya, hubungan antara keparahan kecacatan dan efikasi diri tidak signifikan bagi orang-orang yang menjadi cacat pada anak usia dini. Temuan-temuan ini diadakan di Holland ranah Realistis, Investigatif, Artistik, Sosial, Enterprising dan Conventional, ketika mengendalikan berbagai masukan orang lain dan pengalaman pembelajaran domain- khusus (Tenenbaum, Byrne, \& Dahling, 2014).

3. Assessing the congruence of worker and workplace using the proximities of their RIASEC types

Inventarisasi minat kejuruan sering dirancang, dinilai dan ditafsirkan sesuai dengan enam jenis tipe Holland (R, I, A, S, E dan C) dan pengaturan heksagonal. Kode tiga huruf kemudian mengidentifikasi tiga jenis yang dinilai paling tinggi oleh orang tersebut. Kesesuaian antara seseorang dan lingkungannya (misalnya, tempat kerja atau bidang studi) dapat memengaruhi kepuasan dan kinerja mereka, dan bagaimana cara mendefinisikan kesesuaian adalah pertanyaan yang sudah lama ada. Metode yang diusulkan di sini didasarkan pada (a) keberadaan dan posisi masing-masing dari enam jenis tipe Holland dalam dua kode tiga huruf yang dibandingkan (atau tidak adanya mereka dari kode) dan (b) perkiraan semua pasangan jenis, yang mencerminkan susunan heksagonal dari jenis. Ada pembahasan tentang apakah pengaturan heksagonal harus digunakan dalam menghitung kongruensi, tetapi jawaban yang pasti belum jelas (Hutchinson, 2014).

4. Orientasi Minat Kejuruan pada Siswa SMA

Penelitian ini digunakan untuk mengklasifikasikan siswa menurut jenis sekolah dan minatnya. Hasil yang ditemukan menggambarkan bahwa tools ini bermanfaat untuk mengukur minat kejuruan siswa di Indonesia. Model hexagonal dari teori Holland yang menyatakan adanya 6 kepribadian yaitu: Tipe Realistik (The Realistic Type (R)), Tipe Peneliti/Pengusut (The Investigative Type (I)), Tipe Seniman (The Artistic Type (A)), Tipe Sosial (The Sosial Type (S)), Tipe Pengusaha (The Enterprising Type (E)), dan Tipe Orang Rutin (Conventional Type (C)) atau dengan singkatan R-I-A-S-E-C. Walaupun hasil penelitian tidak menjelaskan tipologi kepribadian tiap siswa, namun jurusan ini mencerminkan tipologi suatu kelompok, dan hasilnya sebagai berikut. Orientasi minat kejuruan pada jurusan IPS tipologi sosial lebih dominan pada jurusan ini dan bersifat universal yaitu dari dimensi aktivitas, kemampuan dan pekerjaan. Ini artinya orientasi minat kejuruan pada siswa jurusan IPS di SMA Negeri 2 Blora terdapat pada tipologi sosial, sedangkan orientasi minat kejuruan pada jurusan IPA tipologi Investigatif lebih dominan pada jurusan ini dan bersifat universal yaitu dari dimensi aktivitas, kemampuan dan pekerjaan. Ini artinya orientasi minat kejuruan pada siswa jurusan IPA di SMA Negeri 2 Blora terdapat pada tipologi investigatif. Walaupun hasil penelitian ini sudah dapat memilah minat dari 2 jurusan SMA namun belum memilah semua jurusan yang ada terlebih di SMK (Rahmantyo, 2015).

\section{APLIKASI TEORI HOLLAND DALAM BK KARIR}

Salah satu implikasi nyata teori Holland untuk konseling karir adalah bahwa praktisi dapat membantu klien menilai kepentingan dan lingkungan kerja mereka dan memahami hubungan di antara mereka (Xu, 2020). Cukup mengembangkan struktur kognitif atau kerangka kerja untuk melihat diri mereka dan pekerjaan sangat membantu banyak orang. Beberapa konselor karir mengatur dan mereferensi karir dan informasi pekerjaan mereka sesuai dengan jenis Holland, menggunakan kode tiga poin yang sesuai dengan jenis yang paling menonjol. Ini memudahkan proses matching interest dan environment (Kulcsár, Dobrean, \& Gati, 2020; Savickas, 2015). 
Menurut Holland suatu minat yang menyangkut pekerjaan dan okupasi adalah hasil perpaduan dari sejarah hidup seseorang dan keseluruhan kepribadiannya, sehingga minat tertentu akhirnya menjadi suatu ciri kepribadian yang berupa ekspresi diri dalam bidang pekerjaan, bidang studi akademik, hobi inti, berbagai kegiatan rekreatif dan banyak kesukaan yang lain (Winkel \& Hastuti, 2005).

Model pilihan karir Holland menunjukkan bahwa individu akan mencari lingkungan kerja yang sesuai dengan keterampilan, kemampuan, sikap, dan nilai mereka atau harus terdapat kesesuaian antara RIASEC dengan lingkungan. Holland membagi kepribadian tersebut dalam enam tipe yaitu Realistic (R), Investigasi (I), Artistik (A), Social (S), Enterprising (E), Ini telah dikenal sebagai model RIASEC (Gorji, Hatamy, \& Khoshkonesh, 2011).

Salah satu implikasi nyata teori Holland untuk konseling karir adalah bahwa praktisi dapat membantu klien menilai kepentingan dan lingkungan kerja mereka dan memahami hubungan di antara mereka. Cukup mengembangkan struktur kognitif atau kerangka kerja untuk melihat diri mereka dan pekerjaan sangat membantu banyak orang. Beberapa konselor karir mengatur dan mereferensi karir dan informasi pekerjaan mereka sesuai dengan jenis Holland, menggunakan kode tiga poin yang sesuai dengan jenis yang paling menonjol. Ini memudahkan proses matc hing interest dan environment (Suryani, 2020).

\section{KESIMPULAN}

Dari barbagi penjelasan diatas dapat disimpulkan bahwa Holland mengemukakan individu terbagi menjadi 6 tipe kepribadian diantaranya realistik, intelektual, konvensional, enterprising, artistik, dan sosial. Perkembangan tipe kepribadian tersebut akibat dari interaksi dengan lingkungan dan yang menentukan dari tipe kepribadian adalah faktor bawaan diri sendri dan lingkungan. Individu dapat menetukan karir secara gemilang apabila tipe kepribadian yang khas diterima didalam suatu lingkungan kerja, selanjutnya minat yang dimiliki individu yang besar dan sosial yang mendukung utuk bekerja.

\section{DAFTAR RUJUKAN}

Bonitz, V. S., Armstrong, P. I., \& Larson, L. M. (2010). RIASEC interest and confidence cutoff scores: Implications for career counseling. Journal of Vocational Behavior, 76(2), 265-276.

Ferreira, A. I., Rodrigues, R. I., \& da Costa Ferreira, P. (2016). Career interests of students in psychology specialties degrees: psychometric evidence and correlations with the RIASEC dimensions. International Journal for Educational and Vocational Guidance, 16(1), 91-111.

Foutch, H., McHugh, E. R., Bertoch, S. C., \& Reardon, R. C. (2014). Creating and using a database on Holland's theory and practical tools. Journal of Career Assessment, 22(1), 188-202.

Gorji, Z., Hatamy, A., \& Khoshkonesh, A. (2011). The relationship between Holland's personality types and sensation seeking in Firemen and Clerks of municipality. Procedia-Social and Behavioral Sciences, 15, 3737-3742.

Greenhaus, J. H., \& Callanan, G. A. (2006). Encyclopedia of career development: Sage Publications.

Haolah, S., Rohaeti, E. E., \& Rosita, T. (2020). Penerapan Bimbingan Kelompok Teknik Role Playing Untuk Meningkatkan Kematangan Karier. FOKUS (Kajian Bimbingan \& Konseling dalam Pendidikan), 3(1), 1-8.

Hurtado Rúa, S. M., Stead, G. B., \& Poklar, A. E. (2019). Five-Factor Personality Traits and RIASEC Interest Types: A Multivariate Meta-Analysis. Journal of Career Assessment, 27(3), 527-543.

Hutchinson, T. P. (2014). Assessing the congruence of worker and workplace using the proximities of their RIASEC types. Australian Journal of Career Development, 23(3), 133-139.

Juwitaningrum, I. (2013). Program bimbingan karir untuk meningkatkan kematangan karir siswa SMK. PSIKOPEDAGOGIA Jurnal Bimbingan dan Konseling, 2(2), 132-147.

Kulcsár, V., Dobrean, A., \& Gati, I. (2020). Challenges and difficulties in career decision making: Their causes, and their effects on the process and the decision. Journal of Vocational Behavior, 116, 103346.

Lent, R. W., Sheu, H.-B., \& Brown, S. D. (2010). The self-efficacy-interest relationship and RIASEC type: Which is figure and which is ground? Comment on Armstrong and Vogel (2009).

Leung, S. A. (2008). The big five career theories International handbook of career guidance (pp. 115-132): Springer.

Ludwikowski, W. (2013). Ability assessment and vocational outcomes: the impact of utilizing an ability measure in predicting choice, aspirations, and satisfaction.

McKay, D. A., \& Tokar, D. M. (2012). The HEXACO and five-factor models of personality in relation to RIASEC vocational interests. Journal of Vocational Behavior, 81(2), 138-149.

Michalos, S. (2010). Linking career theories to volunteering. Career planning and adult development journal, 26(3), 25. 
Nindya, N. N., Kiswantoro, A., \& Hidayati, R. (2020). Layanan informasi melalui media animasi untuk meningkatkan kematangan karir peserta didik. Jurnal Prakarsa Paedagogia, 2(2).

Patton, W., \& McMahon, M. (2014). Career development and systems theory: Connecting theory and practice (Vol. 2): Springer.

Putri, R. D., \& Sari, S. P. (2018). Implementation of John Holland's Career Theory in Guidance and Counseling. ENLIGHTEN: Jurnal Bimbingan Konseling Islam, 1(2), 126-132.

Rahmantyo, W. A. (2015). Orientasi Minat Kejuruan Pada Siswa SMA. Universitas Muhammadiyah Surakarta.

Rahmawati, A. R., Yusmansyah, Y., \& Mayasari, S. (2020). Pengaruh Layanan Bimbingan Kelompok Terhadap Kematangan Pilihan Karir. ALIBKIN (Jurnal Bimbingan Konseling), 8(2).

Rahmi, A. (2017). Konseling Karir Model Career Development Resource Centre (Cdrc) Di Perguruan Tinggi Untuk Persiapan Tenaga Kerja Menyongsong Masyarakat Ekonomi Asean (Mea)

Proceeding IAIN Batusangkar, 1(1), 34-45.

Rosita, T., Irmayanti, R., \& Hendriana, H. (2020). Urgensi Bimbingan Karir Di Sekolah Dasar

Abdimas Siliwangi, 3(1), 109-205.

Savickas, M. L. (2015). Career counseling paradigms: Guiding, developing, and designing.

Sheldon, K. M., Holliday, G., Titova, L., \& Benson, C. (2020). Comparing Holland and Self-Determination Theory Measures of Career Preference as Predictors of Career Choice. Journal of Career Assessment, 28(1), 28-42.

Sheu, H.-B., Lent, R. W., Brown, S. D., Miller, M. J., Hennessy, K. D., \& Duffy, R. D. (2010). Testing the choice model of social cognitive career theory across Holland themes: A meta-analytic path analysis. Journal of Vocational Behavior, 76(2), 252-264.

Smart, J. C., Feldman, K. A., \& Ethington, C. A. (2000). Academic disciplines: Holland's theory and the study of college students and faculty: Vanderbilt University Press.

Suprihatin, T. (2015). Bimbingan Karir Tehadap Anak Asuh Di Panti Asuhan Al-Khoerot Desa Majasari Kecamatan Bukateja Kabupaten Purbalingga

IAIN Purwokerto.

Suryani, A. I. (2020). Peran Guru Bimbingan Konseling dalam Pemilihan Jurusan di Sekolah Menengah Atas Negeri 2 Siak Hulu Kecamatan Siak Hulu Kabupaten Kampar Provinsi Riau. UNIVERSITAS ISLAM NEGERI SULTAN SYARIF KASIM RIAU.

Tama, A. (2019). Efektivitas Penerapan Teori Karir John L. Holland Terhadap Peningkatan Perencanaan Karir Siswa

Skripsi, Universitas Muhammadiyah Magelang.

Tenenbaum, R. Z., Byrne, C. J., \& Dahling, J. J. (2014). Interactive effects of physical disability severity and age of disability onset on RIASEC self-efficacies. Journal of Career Assessment, 22(2), 274-289.

Wille, B., \& De Fruyt, F. (2014). Vocations as a source of identity: Reciprocal relations between Big Five personality traits and RIASEC characteristics over 15 years. Journal of Applied Psychology, 99(2), 262.

Winkel, W., \& Hastuti, M. S. (2005). Bimbingan dan konseling di institusi pendidikan: Media Abadi.

$\mathrm{Xu}, \mathrm{H}$. (2020). Career indecision profile-short: reliability and validity among employees and measurement invariance across students and employees. Journal of Career Assessment, 28(1), 91-108.

Yusuf, R. M., \& Hasnidar, H. (2020). Work-family conflict and career development on performance of married women employees. International Journal of Research in Business and Social Science (2147-4478), 9(1), 151-162. 